\title{
STUDI TENTANG PELAYANAN FRONT LINE EMPOYER DI PERGURUAN TINGGI
}

\author{
Oleh: \\ Elin Rosalin
}

Universitas Pendidikan Indonesia

(e-mail: rosalin.elin01@upi.edu)

\begin{abstract}
ABSTRAK
Penelitian ini membahas tentang tanggung jawab Front Line employees (FLE) yang memiliki peran penting dalam menunjang keberhasilan penyampaian jasa untuk mendukung tercapainya kepuasan pelanggan melalui penyampaian service encounter. Penelitian ini bertujuan untuk mengetahui pengaruh service encounter terhadap kualitas jasa dan dampaknya terhadap service recovery effort yang dilakukan serta switching intention. Metode yang digunakan adalah Metode Survei Penjelasan (Explanatory Survei Method). Sebagai bentuk penelitian kualitatif fokusnya terletak pada penjelasan hubungan sebab akibat. Populasi penelitian yakni mahasiswa di perguruan tinggi di Jawa Barat yang terdiri dari PTN non Badan Hukum Milik Negara (BHMN), PTN BHMN, Perguruan Tinggi Swasta (PTS) terakreditasi, PTS non akreditasi. Hasil penelitian menunjukan secara umum pelayanan administratif pada 4 perguruan tinggi yaitu PTN BHMN, PTN Non BHMN, PTS Akreditasi dan PTN Non Akreditasi tidak menunjukkan perbedaan yang signifikan. Kinerja penyampaian jasa pada keempat jenis perguruan tinggi tersebut menunjukkan pada kisaran yang cukup baik, khususnya dalam aspek seleksi penerimaan mahasiswa baru, persiapan kuliah dan kuliah serta ujian. Temuan penting dari penelitian ini adalah seluruh perguruan tinggi tersebut masih belum menunjukkan kinerja penghantaran jasa yang optimal, khususnya pada aspek sikap pelayanan karyawan administrasi. Secara umum sikap karyawan pada saat melakukan kontak masih jauh dari memadai.
\end{abstract}

Kata Kunci: Kenyamanan Layanan, Kualitas Layanan, Pertemuan Layanan, dan Pemulihan Layanan.

\section{ABSTRACT}

This study discusses the responsibilities of Front Line employees (FLE) who have an important role in supporting the success of service delivery to support the achievement of customer satisfaction through the delivery of service encounters. This study aims to determine the effect of service encounter on service quality and its impact on the service recovery effort carried out and switching intention. The method used is the Survey Explanation Method (Explanatory Survey Method). As a form of qualitative research the focuslies in the explanation of causal relationships. The study population was students in universities in West Java consisting of non-state-owned legal entities (BHMN), BHMN PTNs, accredited private colleges (PTS), non-accredited PTS. The results of the study showed that in general administrative services at 4 universities, namely PTN BHMN, Non BHMN PTN, Accreditation PTS and Non-Accreditation PTN did not show significant differences. The performance of service delivery in the four types of tertiary institutions shows a fairly good range, especially in the aspect of selection of new admissions, college preparation and lectures and examinations. An important finding from this research is that all of these universities have not shown optimal service delivery performance, especially in the aspect of service attitude of administrative employees. In general, the attitude of employees when making contact is still far from adequate.

Keyword: Effort, Service Encounter, Service Quality Service Convenience, Service Recovery, and Switching Intension

\section{PENDAHULUAN}

Fenomena ditingkat lokal, nasional, regional, dan internasional dalam beberapa dasawarsa terakhir adalah meningkatnya perkembangan pendidikan tinggi (higher atau tertiary education). pada 2004, terdapat 81 lembaga pendidikan tinggi di bawah Depdiknas dan 59 di bawah Depag dengan jumlah mahasiswa lebih dari 880 ribu orang; sementara itu, terdapat sekitar 2.236 lembaga pendidikan swasta dengan jumlah mahasiswa sekitar 1,7 juta orang (Azra, Republika Online, 7 September 2006).

Sejauh ini aspek peningkatan kuantitas PT belum diikuti dengan peningkatan kualitas (Azra, 2006). Upaya peningkatan kualitas PT dapat ditinjau melalui input, proses dan output. 
Pemasaran jasa merupakan pendekatan untuk meningkatkan kualitas pendidikan melalui upaya untuk meningkatkan service excellence dalam proses penyampaian jasa dan mengurangi kesenjangan antara harapan user dengan apa yang diberikan oleh service provider.

Jika ditinjau dari karakteristiknya produk PT sepenuhnya adalah jasa kependidikan yang terdiri atas jasa kurikuler (JK), jasa penelitian (JP), jasa pengabdian kepada masyarakat (JPM), jasa administrasi (JA) dan jasa ekstrakurikuler (JE), sedangkan lulusannya adalah produk parsial karena sesungguhnya mahasiswa pada akhirnya lulus bukan hanya karena jasa-jasa PT saja melainkan juga karena adanya potensi dan usaha mahasiswa.

Merujuk pada bentuk jasa administrasi (JA) yang disampaikan oleh perguruan tinggi terdapat beberapa fenomena kegagalan service encounter seperti: pelayanan yang lamban, pelayanan yang tidak ramah, pemberian informasi yang tidak akurat (jadwal kuliah, jadwal bimbingan, nilai), tidak memberikan informasi yang dibutuhkan tanpa alasan yang jelas dan petugas tidak ada di tempat (Observasi dan wawancara tentang pelayanan administratif terhadap beberapa mahasiswa PTS di Bandung). Hal tersebut tentu tidak mendukung situasi akademik yang kondusif sehingga berisiko menyebabkan ketidaknyamanan, pemborosan waktu maupun keinginan untuk berpindah. Pada gilirannya keinginan untuk berpindah tersebut merupakan kerugian dan menghambat pencapaian tujuan pendidikan nasional.

Seiring upaya tersebut salah satu unsur dalam program pelayanan jasa pendidikan adalah person yaitu sumber daya manusia yang memberikan jasa dan menjadi penghubung antara penyedia jasa dengan pelanggan (Zeithmal dan Bitner, 2000). Frontline employees (FLE) memiliki peran penting dalam menunjang keberhasilan penyampaian jasa. Dalam kaitan ini pentingnya perilaku penyedia jasa (service provider) khususnya FLE terkait dengan upaya untuk membangun kepercayaan konsumen (consumer trust) dan memahami mekanisme perubahan kepercayaan menjadi loyalitas dalam pertukaran relasional.

Dengan demikian peranan FLE dalam proses penyampaian pelayanan (service encounter) diduga dinilai sangat penting dalam pencapaian kinerja pelayanan. Pada penelitian ini akan diungkapkan lebih jauh mengenai bagaimana penyampaian jasa bidang administratif (administrative service encounter) berpengaruh terhadap kualitas pelayanan jasa (service quality). Penelitian ini dinilai penting mengingat, sejalan dengan prospek dan tuntutan perguruan tinggi yang senantiasa berupaya memberikan pelayanan optimal bukan hanya dalam bidang akademik tetapi juga dalam bidang administratif. 


\section{METODE PENELITIAN}

Penelitian dilakukan pada mahasiswa pada perguruan tinggi di Jawa Barat yang terdiri dari PTN non Badan Hukum Milik Negara (BHMN), PTN BHMN, Perguruan Tinggi Swasta (PTS) terakreditasi, PTS non akreditasi.

Penelitian ini menggunakan Metode Survei Penjelasan (Explanatory Survei Method). Metode ini sesuai dengan yang dikemukakan Singarimbun (1993), yaitu dibatasi pada pengertian survei sampel yang bertujuan menguji hipotesis yang telah dirumuskan sebelumnya. Walaupun uraiannya juga mengandung deskripsi, tetapi sebagai bentuk penelitian kualitatif fokusnya terletak pada penjelasan hubungan sebab akibat. Pendekatan kuantitatif dilakukan untuk menjawab hubungan antara variabel. Penelitian dilakukan dengan pendekatan kualitatif dan kuantitatif. Pendekatan kualitatif diarahkan untuk menjawab:

1. Jenis-jenis administrative service encounter

2. Program service recovery

3. Kualifikasi FLE

4. Tingkat Kualitas Jasa

\section{HASIL PENELITIAN}

Deskripsi Pelayanan Bagi Mahasiswa di

\section{Perguruan Tinggi}

Sistem pelayanan bagi mahasiswa di Perguruan Tinggi baik Perguruan Tinggi Negeri (PTN), Perguruan Tinggi Negeri BHMN, Perguruan Tinggi Swasta (PTS) akreditasi dan PTS non akreditasi bertumpu pada dua jenis pelayanan, yaitu pelayanan akademik dan pelayanan administratif. Pelayanan akademik adalah pelayanan yang diberikan kepada mahasiswa berkaitan dengan kegiatan akademik yang dilakukan. Pelayanan akademik ini meliputi pelayanan-pelayanan berupa konsultasi dan bimbingan terstruktur. Konsultasi dapat dilakukan mahasiswa setiap saat tanpa harus terikat oleh waktu/jadwal tertentu. Pelayanan konsultasi berkaitan dengan kesulitan belajar dan hal-hal yang bersifat psikologis dilayani langsung oleh unit konselor (penasihat) profesional, yang dikoordinasikan di tingkat institut. Bimbingan yang lebih terstruktur dilakukan melalui mekanisme perwalian yang diselenggarakan dua kali dalam setiap semester.

Sedangkan pelayanan administrasi adalah pelayanan yang diberikan kepada mahasiswa berkaitan dengan kebutuhan mahasiswa terhadap perijinan atau kelengkapan-kelengkapan administrasi jurusan. Mahasiswa diharapkan memperhatikan bahwa beberapa proses administrasi memerlukan waktu untuk penyelesaiannya. Oleh karena itu mahasiswa diharapkan menyediakan cukup waktu untuk penyelesaian kebutuhan administrasinya.

Adapun beberapa jenis layanan administratif yang diberikan adalah:

\section{a. Penerimaan Mahasiswa Baru}

Jenis-jenis penerimaan mahasiswa baru antara lain 
1) Penerimaan Mahasiswa Pindahan dari Perguruan Tinggi Lain

2) Penerimaan Mahasiswa Baru

\section{b. Registrasi}

Registrasi terdiri dari (1) Registrasi Awal, yaitu regristrasi yang dilakukan pada saat pertama kali terdaftar di perguruan tinggi yang bersangkutan dan (2) Registrasi Ulang, yaitu registrasi berikutnya setelah registrasi awal yang dilakukan setiap semester untuk mengikuti pendidikan pada semester yang bersangkutan.

\section{c. Pelayanan Jadwal Kuliah dan Ujian}

Pelayanan ini mencakup penyampaian informasi tentang jadwal kuliah yang mencakup waktu, tempat, pengajar (dosen) dan beban SKS. Dalam kaitan tersebut informasi tentang ujian sebagai bagian penting dari program evaluasi perkuliahan dapat diberikan mencakup tempat, waktu, pengawas dan jenis ujian (close book atau open book).

\section{Hasil Uji Validitas dan Reliabilitas}

\section{a. Variabel Service Encounter $\left(\mathrm{X}_{1}\right)$}

Variabel ini berupaya mengungkap tentang bagaimana kinerja pelayanan pada saat mahasiswa melakukan kontak administratif dengan pihak perguruan tinggi. Pada variabel ini pilihan jawaban item terdiri dari 3 aspek yang ditanyakan yaitu kecepatan, kejelasan dan ketepatan dengan dengan skala 1-5.
Untuk aspek kecepatan merupakan kecepatan penyampaian informasi yang dibutuhkan oleh mahasiswa. Nilai-nilai skala dijelaskan sebagai berikut: (1) 5 = Sangat Cepat, (2) 4 = Cepat, (3) 3 = Cukup Cepat, (4) $2=$ Lambat dan (1) 1 = Sangat Lambat

Untuk aspek kejelasan merupakan kejelasan informasi oleh staf administrasi ketika memberikan pelayanan. Nilai-nilai skala dijelaskan sebagai berikut: (1) $5=$ Sangat Jelas, (2) 4 = Jelas, (3) $3=$ Kurang Jelas, (4) 2 $=$ Tidak Jelas dan (1) 1 = Sangat Tidak Jelas

Untuk aspek akurasi merupakan ketepatan informasi yang diberikan oleh staf administrasi ketika memberikan pelayanan. Nilai-nilai skala dijelaskan sebagai berikut: (1) $5=$ Sangat tepat, (2) $4=$ Tepat, (3) $3=$ Kurang tepat, (4) 2 = Tidak Tepat dan (1) 1 = Sangat Tidak Tepat.

Pada variabel ini juga ditanyakan mengenai sikap petugas administratif ketika memberikan pelayanan kepada mahasiswa, dengan pilihan skala: (1) Sangat Tidak ramah, (2) Tidak ada ekspresi, (3) Tidak Tahu, (4) Cukup Ramah dan (5) Sangat Ramah.

Adapun hasil uji validitas dan reliabilitas pada variabel service encounter $\left(\mathrm{X}_{1}\right)$ dijelaskan pada Tabel 4.1 sebagai berikut:

Tabel 1 Hasil Uji Validitas dan Reliabilitas Variabel Service Encounter (X1) 


\begin{tabular}{|c|c|c|c|c|c|c|c|}
\hline \multirow[b]{2}{*}{ Indikator } & \multirow[b]{2}{*}{$\begin{array}{l}\text { No } \\
\text { Item }\end{array}$} & \multicolumn{3}{|c|}{ Uji Validitas (UV) } & \multirow{2}{*}{$\begin{array}{c}\text { Uji } \\
\text { Reliabilitas } \\
\text { (UR) } \\
\text { Cronbach } \\
\alpha\end{array}$} & \multicolumn{2}{|c|}{ Keterangan } \\
\hline & & $\mathbf{r}$ & $\mathbf{p}$ & $\alpha$ & & $\mathbf{U V}$ & UR \\
\hline $\begin{array}{l}\text { Seleksi Penerimaan } \\
\text { Mahasiswa Baru }\end{array}$ & $1-3$ & 0.571 & 0,000 & 0,05 & 0,842 & V & $\mathrm{R}$ \\
\hline Persiapan Kuliah & $4-6$ & 0,582 & 0,000 & 0,05 & 0,848 & V & $\mathrm{R}$ \\
\hline Perkuliahan dan Ujian & $7-14$ & 0.541 & 0,000 & 0,05 & 0,825 & V & $\mathrm{R}$ \\
\hline $\begin{array}{ll}\text { Sikap } & \text { Petugas } \\
\text { Administratif } & \end{array}$ & $\begin{array}{l}15- \\
19\end{array}$ & 0,551 & 0,000 & 0,05 & 0,831 & $\mathrm{~V}$ & $\mathrm{R}$ \\
\hline
\end{tabular}

Ket:

$\mathrm{V}=$ Valid

$\mathrm{R}=$ Reliabel

\section{b. Variabel Service Quality $\left(\mathrm{X}_{2}\right)$}

Untuk variabel ini tidak dilakukan pengujian validitas dan reliabilitas karena instrumen sudah dianggap baku yaitu instrumen yang dikembangkan oleh Zeithaml dan Parasuraman (1999).

\section{c. Variabel Service Recovery Effort (Y)}

Hasil uji validitas dan reliabilitas pada variabel service recovery effort (Y) yang terdiri dari 3 item dapat diketahui bahwa pada indikator ini nilai $\mathrm{r}$ mencapai $0,570, \mathrm{p}=0,000$ $<\alpha=0,05$ yang menunjukkan bahwa item pada indikator ini adalah valid. Adapun Cronbach Alpha yang dicapai adalah 0,841 yang menunjukkan bahwa item pada indikator peluang untuk berkembang termasuk kategori reliabel karena memenuhi syarat reliabilitas yaitu Cronbach $\alpha>0,8$.

\section{d. Variabel Switching Intention (Z)}

Adapun hasil uji validitas dan reliabilitas pada variabel switching intention (Z) yang terdiri dari 3 item dapat diketahui bahwa pada indikator ini nilai $r$ mencapai $0,581, \mathrm{p}=0,000<\alpha=0,05$ yang menunjukkan bahwa item pada indikator ini adalah valid.

Adapun Cronbach Alpha yang dicapai adalah 0,871 yang menunjukkan bahwa item pada indikator peluang untuk berkembang termasuk kategori reliabel karena memenuhi syarat reliabilitas yaitu Cronbach $\alpha>0,8$.

\section{Deskripsi Objek Penelitian}

\section{a. Gambaran Organisasi Perguruan Tinggi}

Pendidikan tinggi adalah kelanjutan pendidikan menengah yang diselenggarakan untuk menyiapkan peserta didik menjadi anggota masyarakat yang memiliki kemampuan akademik dan atau profesional yang menerapkan, mengembangkan dan menciptakan ilmu pengetahuan, teknologi dan kesenian. Sedangkan yang dimaksud dengan perguruan tinggi adalah satuan pendidikan yang menyelenggarakan pendidikan tinggi dan dapat berbentuk akademi, politeknik, sekolah tinggi, institut dan universitas.

$$
\text { Perguruan tinggi yang }
$$
menyelenggarakan pendidikan sampai dengan tingkat sarjana adalah terdiri dari: (1) Sekolah tinggi menyelenggarakan program pendidikan akademik dan/ atau profesional dalam lingkup 
satu disiplin ilmu tertentu, (2) Institut menyelenggarakan program pendidikan akademik dan/atau profesional dalam sekelompok disiplin ilmu pengetahuan, teknologi dan/atau kesenian yang sejenis, (3) Universitas menyelenggarakan program pendidikan akademik dan/atau profesional dalam sejumlah disiplin ilmu pengetahuan, teknologi dan/atau kesenian tertentu.

Perguruan tinggi terdiri atas unsurunsur sebagai berikut: (1) dewan penyantun, (2) unsur pimpinan, (3) unsur tenaga pengajar para dosen, (4) senat perguruan tinggi, (5) unsur pelaksana akademik, yang terdiri dari : (a) bidang pendidikan, (b) bidang penelitian dan (c) bidang pengabdian kepada masyarakat, (6) unsur pelaksana administratif; (7) unsur penunjang untuk pelaksana yang meliputi : (a) perpustakaan; (b) laboratorium; (c) bengkel, (d) kebun percobaan; (e) pusat komputer; (f) bentuk lain yang dianggap perlu untuk mendukung penyelenggaraan pendidikan akademik dan/atau profesional pada perguruan tinggi yang bersangkutan.

Adapun Organisasi universitas/institut terdiri atas : (1) unsur pimpinan : Rektor dan Pembantu Rektor, (2) senat universitas/institute, (3) unsur pelaksana akademik : fakultas, lembaga penelitian, dan lembaga pengabdian kepada masyarakat; (4) unsur pelaksana administrasi : biro, (5) unsur penunjang : unit pelaksana teknis; (6) unsur lain yang dianggap perlu.

Organisasi fakultas terdiri dari: (1) unsur pimpinan: Dekan dan Pembantu Dekan;
(2) senat fakultas; (3) unsur pelaksana akademik: jurusan, laboratorium, dan kelompok dosen dan (4) unsur pelaksana administratif: bagian tata-usaha.

Selain Universitas juga terdapat Sekolah Tinggi yang dapat menyelenggarakan pendidikan tingkat Sarjana. Sekolah tinggi merupakan perguruan tinggi yang menyelenggarakan pendidikan profesional dan/atau program pen-didikan akademik. Organisasi sekolah tinggi terdiri atas : (1) unsur pimpinan : Ketua dan Pembantu Ketua; (2) senat sekolah tinggi; (3) unsur pelaksana akademik : jurusan, pusat penelitian dan pengabdian kepada masyarakat, laboratorium/studio dan kelompok dosen; (4) unsur pelaksana administratif : bagian; (5) unsur penunjang : unit pelaksana teknis; (6) unsur lain yang dianggap perlu.

Sekolah tinggi dipimpin oleh seorang Ketua dan dibantu oleh Pembantu Ketua yang terdiri atas Pembantu Ketua bidang Akademik, Pembantu Ketua bidang Administrasi Umum, dan Pembantu Ketua bidang Kemahasiswaan.

\section{b. Gambaran Perguruan Tinggi Negeri BHMN}

Perguruan Tinggi Badan Hukum Milik Negara adalah badan hukum pendidikan sebagaimana dimaksud dalam Penjelesan Pasal 53 ayat (1) UU Nomor 20 Tahun 2003 yang bertugas menyelenggarakan layanan Tridharma pendidikan tinggi, yang selanjutnya disebut PT-BHMN. Perguruan Tinggi Negeri adalah satuan pendidikan milik negara yang menyelenggarakan layanan pendidikan tinggi; 
Perguruan tinggi milik negara ditetapkan sebagai PT-BHMN dengan peraturan pemerintah setelah melalui suatu proses pengkajian yang mendalam atas usulan dan rencana pengembangan yang diajukan oleh Menteri. Peraturan pemerintah sekurang kurangnya mememuat:

(1) Penetapan perguruan tinggi sebagai badan layanan umum yang berstatus badan hukum milik negara.

(2) Anggaran dasar.

(3) Penunjukan Menteri untuk melaksanakan pembinaan secara umum.

Adapun prasyarat perguruan tinggi untuk ditetapkan sebagai PT-BHMN:

(1) Kemampuan untuk menyelenggarakan PTBHMN yang berkualitas.

(2) Kemampuan untuk memenuhi standar minimum finansial.

(3) Kemampuan untuk mengelola perguruan tinggi dengan prinsip ekonomis dan akuntabel. Pemerintah menyerahkan hak pengelolaan atas kekayaan yang ada pada PTBHMN untuk digunakan buat pelaksanaan layanan pendidikan tinggi. Pengalihan hak milik dan penghapusan kekayaan negara yang diserahkan hak pengelolaannya kepada PTBHMN dapat dilakukan atas izin tertulis dari Menteri Keuangan setelah mendapat persetujuan dari Menteri dan MWA. Penerimaan PT-BHMN berasal dari subsidi dan bantuan Pemerintah dan pemerintah daerah, dana masyarakat, hibah dari dalam dan luar negeri, usaha yang sah, pinjaman dan sumber penerimaan lainnya yang sah.
Pemerintah memberikan bantuan dan subsidi untuk penyelenggaraan pendidikan kepada PTBHMN sesuai dengan prestasi kerja yang ditetapkan Menteri.

Ketentuan lebih lanjut tentang Penerimaan dan Pengeluaran PT-BHMN ditetapkan dalam Status PT-BHMN sesuai dengan peraturan perundangan yang berlaku. PT-BHMN dapat mendirikan satuan pendidikan lain yang kegiatannya sesuai dengan maksud dan tujuan PT-BHMN atas persetujuan MWA. PT-BHMN dapat mendirikan unit usaha yang terkait dengan tugas dan fungsinya atas persetujuan MWA.

Organisasi PT-BHMN terdiri atas Majelis Wali Amanat, Dewan Audit, Senat Akademik, Dewan Guru Besar, Pimpinan, Tenaga Kependidikan, Tenaga Administrasi, dan unsur penunjang. Unsur pelaksana akademik terdiri dari fakultas, lembaga, pusat, pusat antar universitas dan bentuk lain yang dianggap perlu. Unsur pelaksana administrasi terdiri dari direktorat, biro, kantor, bagian, dan bentuk lain yang dianggap perlu. Unsur penunjang terdiri dari perpustakaan, laboratorium, bengkel, pusat layanan teknologi informasi dan komunikasi, kebun percobaan, dan bentuk lain yang dianggap perlu. Organisasi yang dibutuhkan pada perguruan tinggi ditetapkan dalam anggaran dasar masing-masing.

\section{Deskripsi Variabel Penelitian}

a. Variabel Service Encounter (SE)

(1) Kondisi Service Encounter Pelayanan Penerimaan Mahasiswa Baru 
Berdasarkan hasil penelitian (lihat lampiran 1) kondisi service encounter pada saat penerimaan mahasiswa baru menunjukkan bahwa:

(a) Kondisi SE penerimaan mahasiswa baru tertinggi adalah pada PT BHMN yaitu ratarata 67,78 atau termasuk kategori cukup baik

(b) Kondisi SE penerimaan mahasiswa baru terendah adalah pada PTS Akreditasi yaitu rata-rata 61,2 atau termasuk kategori cukup baik.

(c) Secara umum ke empat jenis perguruan tinggi tersebut tidak menunjukkan perbedaan pelayanan yang signifikan dalam hal penerimaan mahasiswa baru.

Berdasarkan hasil di atas dapat dipahami mengingat PT BHMN dan PTN sejauh ini dianggap paling siap dalam menentukan jalur penerimaan mahasiswa baru, baik melalui jalur SPMB maupun non SPMB.

(2) Kondisi Service Encounter Persiapan Kuliah

Berdasarkan hasil penelitian (lihat lampiran 1) kondisi service encounter pada saat persiapan kuliah menunjukkan bahwa:

(a) Kondisi SE persiapan kuliah tertinggi adalah pada PT Akreditasi yaitu rata-rata 67,33 atau termasuk kategori cukup baik

(b) Kondisi SE persiapan kuliah terendah adalah pada PTN Non akreditasi yaitu ratarata 64,95 atau termasuk kategori cukup baik.

(c) Secara umum ke empat jenis perguruan tinggi tersebut tidak menunjukkan perbedaan pelayanan yang signifikan dalam hal persiapan kuliah.

Hasil tersebut dapat diketahui bahwa sejauh ini dalam informasi persiapan kuliah pihak PTS Akreditasi memiliki kinerja service encounter yang paling tinggi dibandingkan 3 jenis perguruan tinggi yang lain. Kinerja tersebut mencakup registrasi, pengambilan Kartu Rencana Studi dan pengesahan KRS.

(3) Kondisi Service Encounter Perkuliahan dan Ujian

Berdasarkan hasil penelitian (lihat lampiran 1) kondisi service encounter pada saat perkuliahan dan ujian menunjukkan bahwa:

(a) Kondisi SE perkuliahan dan ujian tertinggi adalah pada PTS Non Akreditasi yaitu rata-rata 62,97 atau termasuk kategori cukup baik.

(b) Kondisi SE perkuliahan dan ujian terendah adalah pada PTN BHMN yaitu rata-rata 61,35 atau termasuk kategori cukup baik.

(c) Secara umum ke empat jenis perguruan tinggi tersebut tidak menunjukkan perbedaan pelayanan yang signifikan dalam hal perkuliahan dan ujian.

Berdasarkan hasil tersebut dapat diketahui bahwa sejauh ini dalam informasi persiapan kuliah pihak PTS Non Akreditasi memiliki kinerja service encounter yang paling tinggi dibandingkan 3 jenis perguruan tinggi yang lain. Kinerja tersebut mencakup pelayanan kontak pada saat penyampaian informasi jadwal kuliah, informasi ruangan 
kuliah, informasi jadwal ujian utama, informasi ujian remedial, informasi jadwal kuliah pengganti, informasi nilai, informasi keterlambatan kuliah dan informasi pembatalan kuliah.

\section{(4) Kondisi Service Encounter Sikap} Karyawan Administratif pada Saat Memberikan Pelayanan Kontak

Berdasarkan hasil penelitian (lihat lampiran 1) kondisi service encounter yang ditunjukkan melalui sikap karyawan administratif pada saat kontak dengan mahasiswa adalah sebagai berikut:

(a) Kondisi SE sikap karyawan administratif tertinggi adalah pada PTN Non BHMN yaitu rata-rata 59,66 atau termasuk kategori kurang baik

(b) Kondisi SE sikap karyawan administratif terendah adalah pada PTS Non Akreditasi yaitu rata-rata 54,24 atau termasuk kategori kurang baik.

(c) Secara umum ke empat jenis perguruan tinggi tersebut tidak menunjukkan perbedaan pelayanan yang signifikan dalam hal sikap karyawan administrasi dan bahkan termasuk kategori kurang baik.

Berdasarkan hasil tersebut dapat diketahui bahwa sejauh sikap tenaga administrasi dalam memberikan pelayanan kontak yaitu mencakup pelayanan tatap muka, menerima telepon, menerima pengaduan, dimintai penjelasan dan diketahui melakukan kesalahan cenderung menunjukkan sikap yang kurang baik. Hal tersebut terjadi pada empat jenis perguruan tinggi yaitu PTN BHMN, PTN non BHMN, PTS Akreditasi dan PTS Non Akreditasi.

b. Variabel Service Quality (X2)

(1) Tangibility

Berdasarkan hasil penelitian (lihat lampiran 1) kondisi tangibility dalam pelayanan administratif pada saat kontak dengan mahasiswa adalah sebagai berikut:

(a) Kondisi tangibility tertinggi adalah pada PTN Non BHMN yaitu rata-rata 0.88 atau termasuk kategori sangat baik

(b) Kondisi tangibility terendah adalah pada PTS Non Akreditasi yaitu rata-rata 0,60 atau termasuk kategori cukup baik.

(c) Secara umum ke empat jenis perguruan tinggi tersebut menunjukkan perbedaan pelayanan yang signifikan dalam hal tangibility pada saat memberikan pelayanan administratif

Berdasarkan hasil tersebut dapat diketahui bahwa sejauh ini aspek tangibility dalam pelayanan administrative yang mencakup: (1) kerapihan baju tenaga administrasi, (2) penampilan tenaga administrasi, (3) alat-alat kerja yang dipergunakan dan (4) ruang pelayanan administrasi menunjukkan kondisi yang berbeda antara PTN BHMN, PT Non BHMN, PTS Akreditasi dan PTS Non Akreditasi.

\section{(2) Responsibility dan Empati}

Berdasarkan hasil penelitian (lihat lampiran 1) kondisi responsibility dan empaty dalam pelayanan administratif pada saat 
kontak dengan mahasiswa adalah sebagai berikut:

(a) Kondisi responsibility dan empaty tertinggi adalah pada PTN Non BHMN yaitu rata-rata 0.72 atau termasuk kategori cukup baik.

(b) Kondisi tangibility terendah adalah pada PTS Non Akreditasi yaitu rata-rata 0,63 atau termasuk kategori cukup baik.

(c) Secara umum ke empat jenis perguruan tinggi tersebut tidak menunjukkan perbedaan pelayanan yang signifikan dalam hal tangibility pada saat memberikan pelayanan administratif.

Berdasarkan hasil tersebut dapat diketahui bahwa sejauh ini aspek responsibility dan empaty dalam pelayanan administratif yang mencakup: (1) tanggung jawab penyelesaian tugas dan (2) bantuan untuk menjelaskan permasalahan menunjukkan kondisi yang berbeda antara PTN BHMN, PT Non BHMN, PTS Akreditasi dan PTS Non Akreditasi.

\section{(3) Responsiveness (Daya Tanggap)}

Berdasarkan hasil penelitian (lihat lampiran 1) kondisi daya tanggap dalam pelayanan administratif pada saat kontak dengan mahasiswa adalah sebagai berikut:

(a) Kondisi daya tanggap tertinggi adalah pada PTN Non BHMN yaitu rata-rata 0.75 atau termasuk kategori cukup baik.

(b) Kondisi daya tanggap terendah adalah pada PTS Non Akreditasi yaitu rata-rata 0,63 atau termasuk kategori cukup baik. (c) Secara umum ke empat jenis perguruan tinggi tersebut tidak menunjukkan perbedaan pelayanan yang signifikan dalam hal daya tanggap pada saat memberikan pelayanan administratif.

Berdasarkan hasil tersebut dapat diketahui bahwa sejauh ini aspek responsibility dan empaty dalam pelayanan administratif yang mencakup: (1) tanggapan terhadap pengaduan, (2) daya tanggap terhadap permasalahan dan (3) daya tanggap terhadap kritik dan saran menunjukkan kondisi yang tidak berbeda antara PTN BHMN, PT Non BHMN, PTS Akreditasi dan PTS Non Akreditasi.

\section{(4) Akurasi}

Berdasarkan hasil penelitian (lihat lampiran 1) kondisi akurasi dalam pelayanan administratif pada saat kontak dengan mahasiswa adalah sebagai berikut:

(a) Kondisi akurasi tertinggi adalah pada PTN Non BHMN yaitu rata-rata 0.75 atau termasuk kategori cukup baik.

(b) Kondisi daya tanggap terendah adalah pada PTS Akreditasi yaitu rata-rata 0,58 atau termasuk kategori kurang baik.

(c) Secara umum ke empat jenis perguruan tinggi tersebut tidak menunjukkan perbedaan pelayanan yang signifikan dalam hal daya tanggap pada saat memberikan pelayanan administrative.

Hasil tersebut dapat diketahui bahwa sejauh ini aspek responsibility dan empaty dalam pelayanan administratif yang mencakup: (1) ketepatan informasi, (2) 
ketepatan pelayanan dan (3) ketepatan penyelesaian masalah menunjukkan kondisi yang tidak berbeda antara PTN BHMN, PT Non BHMN, PTS Akreditasi dan PTS Non Akreditasi.

\section{c. Variabel Service Recovery Effort (Y)}

Variabel ini mengungkapkan upaya perguruan tinggi dalam memperbaiki kegagalan jasa yang telah dilakukan. Berdasarkan hasil penelitian dapat diketahui bahwa upaya service recovery yang mencakup (1) memberikan penjelasan ketika terjadi kesalahan, (2) penggantian jadwal ketika terjadi pembatalan kuliah dan (3) kerugian akibat keterlambatan pelayanan pada empat jenis perguruan tinggi tersebut berada pada kondisi kurang baik. Kondisi tersebut adalah:

(1) Pada PTN BHMN tingkat SRE hanya mencapai 44,27 \% atau termasuk kategori kurang baik.

(2) Pada PTN Non BHMN tingkat SRE hanya mencapai $48,76 \%$ atau termasuk kategori kurang baik.

(3) Pada PTS Akreditasi tingkat SRE hanya mencapai 50,13 \% atau termasuk kategori kurang baik.

(4) Pada PTS Non Akreditasi tingkat SRE hanya mencapai $41,47 \%$ atau termasuk kategori kurang baik.

Hasil tersebut menunjukkan bahwa keempat jenis perguruan tinggi tersebut belum melakukan upaya yang optimal untuk melakukan perbaikan atas kesalahan yang telah dilakukan dalam proses pelayanan.

\section{d. Variabel Switching Intention Mahasiswa} (Z)

Variabel ini mengungkapkan bagaimana perasaan atau keinginan berpindah mahasiswa sebagai akibat dari pelayanan administrative yang diterimanya. Berdasarkan hasil penelitian dapat diketahui bahwa upaya keinginan berpindah mahasiswa yang mencakup perasaan (1) bahwa pelayanan administrative menimbulkan keinginan untuk berpindah, (2) tidak mengalami kerugian jika berpindah PT demi mendapatkan pelayanan yang baik dan (3) ingin keluar dari Perguruan tinggi karena merasa pelayanan kurang memadai. Kondisi tersebut adalah:

I. Pada PTN BHMN kondisi SI adalah 50,13 $\%$ atau termasuk kategori cukup rendah.

II. Pada PTN Non BHMN tingkat SI adalah $41,47 \%$ atau termasuk kategori cukup rendah.

III. Pada PTS Akreditasi tingkat SI adalah $48,8 \%$ atau termasuk kategori kurang baik.

IV. Pada PTS Non Akreditasi tingkat SI hanya mencapai 44,27 \% atau termasuk kategori kurang baik.

Hasil di atas menunjukkan bahwa mahasiswa pada keempat jenis perguruan tinggi tersebut tidak menjadikan pelayanan sebagai alasan utama untuk berpindah perguruan tinggi. Hal tersebut dapat dipahami karena switching intention dipengaruhi oleh pertimbangan biaya dan waktu. 
Pada kelompok high contact service seperti yang terjadi di perguruan tinggi, mitra secara aktif terlibat dengan organisasi penyedia jasa dan personilnya selama penyampaian jasa berlangsung. Lebih jauh kualitas jasa yang dievaluasi oleh mitra tersebut secara dominant terjadi pada saat terjadinya penyampaian jasa (service encounter). Lebih jauh secara teoretis Sebagaimana dijelaskan di atas pada saat service encounter ini mitra dapat melakukan evaluasi terhadap pelayanan jasa yang biasanya dirasakan antara lain melalui rasa nyaman atau tidak nyaman selama menerima pelayanan. Dalam kaitan ini consumer convenience orientation adalah melihat mengapa beberapa mitra memilih satu barang atau jasa daripada barang dan jasa yang lainnya. Dimensi Service Convenience mencakup (Berry, Sheiders dan Grewal, 2002):

(1) Decision convenience, yaitu kenyamanan yang mencakup persepsi tentang waktu yang dibutuhkan dan usaha yang dilakukan oleh pelanggan untuk membeli jasa atau memutuskan untuk menggunakan jasa.

(2) Access convenience, yaitu kenyamanan yang merujuk pada persepsi pelanggan tentang waktu yang dibutuhkan dan usaha yang dilakukan untuk memulai jasa yang dibutuhkan.

(3) Transaction convenience, yaitu kenyamanan yang mencakup pada persepsi pelanggan tentang waktu yang dibutuhkan dan usaha yang dilakukan untuk melakukan transaksi jasa. Kenyamanan transaksi ini langsung memfokuskan pada tindakan konsumen untuk menikmati haknya dalam memilih jasa yang akan digunakan.

(4) Benefit convenience, yaitu kenyamanan yang mencakup persepsi tentang waktu yang dibutuhkan dan usaha yang dilakukan oleh konsumen untuk memperoleh pengalaman sebagai produk jasa utama (misalnya, menggunakan taxi atau menonton film).

(5) Post benefit convenience, yaitu kenyamanan yang mencakup persepsi tentang waktu dan usaha yang dibutuhkan oleh konsumen ketika mereka akan melakukan kontak kembali dengan penyedia jasa setelah melakukan transaksi.

Hasil penelitian Berry, Sheiders dan Grewal (2002) menunjukkan bahwa dengan adanya kenyamanan tersebut berpengaruh terhadap service evaluation yang mencakup satisfaction, service quality dan fairness. Adanya kepuasan tersebut diduga menurunkan keinginan konsumen untuk berpindah ke service provider yang lain. Dengan demikian hasil penelitian ini mendukung bahwa service encounter yang diterima mahasiswa merupakan media evaluasi atas pelayanan administrative yang diterimanya. 
Dalam kaitan tersebut evaluasi yang dilakukan oleh mahasiswa mengacu pada gambaran service quality. Sebagaimana dijelaskan, penyampaian jasa melibatkan beberapa tahapan atau proses (Verhoeff et al, 2004). Seperti telah dijelaskan sebelumnya bahwa kegagalan pada tahap servicie encounter dapat menimbulkan biaya yang signifikan seperti mengulangi pekerjaan, memberikan kompensasi, kehilangan pelanggan dan word of mouth negatif (Bitner et al, 1994). Akan tetapi hasil penelitian lain menujukkan bahwa penjelasan tentang kesalahan yang dilakukan service provider dapat meringankan kekecewaan akibat kegagalan penyediaan jasa (Goodwin dan Ross, 1992, Levesquedan McDougall, 2000; Mattila, 2006).

Upaya untuk memberikan kompensasi, memberikan penjelasan kepada konsumen tentang kegagalan penyampaian jasa merupakan upaya yang dilakukan untuk memperbaiki evaluasi konsumen terhadap jasa yang diterimanya. Service recovery merujuk pada sejumlah tindakan yang dilakukan oleh organisasi untuk merespon kegagalan jasa (Zeithaml dan Bitner, 2000). Kegagalan jasa terjadi karena 4 hal yaitu: (a) jasa yang dijanjikan tidak tersedia, (b) jasa yang diberikan lambat, (c) hasil tidak akurat dan (d) karyawan berlaku kasar atau uncaring. Penjelasan atau perbaikan yang diberikan oleh service provider dapat menumbuhkan persepsi fairness bagi konsumen (Shaw, et al, 2003). Persepsi yang terbentuk diharapkan dapat menumbuhkan rasa nyaman dan mengurangi keinginan untuk berpindah. Dengan demikian dapat diduga bahwa upaya service recovery yang dilakukan oleh service provider dapat mempengaruhi hubungan antara keefektifan service encounter dan service quality.

Jika terjadi kegagalan pada service encounter dan evaluasi yang buruk pada service quality dapat dilakukan upaya untuk melakukan service recovery sehingga menghambat keinginan untuk melakukan perpindahan (switching intention).

Tetapi dalam konteks lembaga pendidikan, switching intention tidak secara langsung dirasakan oleh mahasiswa hanya karena disebabkan oleh kualitas pelayanan administratif. Hal tersebut ditunjukkan dengan persentase pengaruh yang kecil antara service quality terhadap switching intention. Kondisi tersebut antara lain didasari oleh alasan bahwa kepentingan mahasiswa terhadap pelayanan pendidikan terkait dengan dimensi waktu dan biaya yang sudah dikorbankan sehingga jika mereka melakukan perpindahan akan mengalami kerugian yang lebih besar.

Sejalan dengan kondisi tersebut Lovelock (dalam Fathulwahid, 2006) mengidentifikasi lima karakteristik yang melekat pada sebuah institusi PT:

a. sifat pelayanan (the nature of the service act). Layanan yang dihasilkan oleh PT lebih mengarah kepada hal yang bersifat intangible - people based - daripada halhal yang bersifat fisik - equipment based. 
Dalam proses pelayanan juga melibatkan aksi-aksi yang intangible.

b. PT terletak pada hubungan dengan konsumen (the relationship with the customer). Layanan pendidikan melibatkan hubungan dengan konsumen yang berlangsung lama dan bersifat formal serta dilakukan terus-menerus (continuous). Mahasiswa sebagai konsumen mempunyai hubungan "keanggotaan" (membership relationship) dengan pihak PT. Hal ini memungkinkan terbentuknya loyalitas konsumen yang tinggi (pihak mahasiswa) dan peningkatan kualitas layanan terhadap konsumen (pihak PT). Tingkat kustomisasi dan penilaian pelayanan (the level of customization and judgment in service delivery) merupakan karakteristik PT,

c. Tingkat kustomisasi pendidikan sangat bervariasi. Tutorial dengan peserta sedikit atau bimbingan individual akan lebih mudah dikustomisasi daripada pendidikan dengan banyak peserta. Semakin terkustomisasinya layanan yang ditawarkan menjadikan konsumen memiliki tingkat pengharapan yang tinggi terhadap kualitas layanan, terutama terkait dengan kualitas staf pengajar. Jika demikian, masalah yang akan muncul adalah kemungkinan adanya hubungan antara kualitas dan tingkat keragaman layanan. Semakin beragam layanan yang ditawarkan, kemungkinan menurunnya kualitas semakin tinggi, d. Terkait dengan sifat permintaan relatif terhadap penawaran (the nature of demand relative to supply). Dalam bidang jasa, terdapat widespread demand (seperti tenaga listrik) dan narrow demand (seperti kamar hotel). Tingkat penawaran untuk memenuhi permintaan yang berfluktuasi sangat berbeda. Peningkatan permintaan tenaga listrik akan lebih mudah dan lebih cepat diatasi dengan meningkatkan kapasitas produksi, jika masih tersedia, dibandingkan dengan peningkatan permintaan terhadap akomodasi hotel. Dalam dunia pendidikan, permintaan terkait dengan narrow demand. Penawaran akan sulit dikelola, karena terkait dengan keterbatasan tenaga pengajar dan program studi yang ditawarkan. Karenanya, selektivitas dalam pendirian program studi baru dan fokus pada pengembangan program studi yang sudah ada harus dipertimbangkan dengan matang,

e. Metode pelayanan (the method of service delivery). Metode pelayanan tergantung pada outlet layanan (single atau multiple) dan sifat interaksi antara konsumen dengan penyedia jasa. Konsumen harus datang ke penyedia jasa dan sebaliknya. Dalam jasa pendidikan, umumnya lembaga pendidikan mensyaratkan konsumen yang datang ke kampus. Namun seiring dengan perkembangan teknologi, memungkinkan dilakukannya distance learning atau elearning. 
Dengan demikian dalam dimensi penyampaian jasa di perguruan tinggi metode pelayanan merupakan salah satu yang turut mendominasi pola hubungan antara perguruan tinggi dengan mahasiswa, akan tetapi masih terdapat unsur-unsur lain yang juga berperan. Factor-faktor lain yang dapat diduga adalah hubungan antara mahasiswa dengan perguruan tinggi, varian atau kustomisasi dari pendidikan dan sifat pelayanan itu sendiri.

\section{SIMPULAN}

Berdasarkan pembahasan dan hasil penelitian dapat dikemukakan bahwa secara umum pelayanan administratif pada 4 perguruan tinggi yaitu PTN BHMN, PTN Non BHMN, PTS Akreditasi dan PTN Non Akreditasi tidak menunjukkan perbedaan yang signifikan. Kinerja penyampaian jasa pada keempat jenis perguruan tinggi tersebut menunjukkan pada kisaran yang cukup baik, khususnya dalam aspek seleksi penerimaan mahasiswa baru, persiapan kuliah dan kuliah serta ujian. Temuan penting dari penelitian ini adalah seluruh perguruan tinggi tersebut masih belum menunjukkan kinerja penghantaran jasa yang optimal, khususnya pada aspek sikap pelayanan karyawan administrasi. Secara umum sikap karyawan pada saat melakukan kontak masih jauh dari memadai.

Dalam kaitan dengan service recovery effort, pada umumnya perguruan tinggi belum melakukan hal yang mengarah pada optimalisasi perbaikan pelayanan. Hal tersebut dapat ditunjukkan pada hasil service recovery effort yang cenderung kurang baik pada seluruh kelompok perguruan tinggi. Akan tetapi jika dikaitkan dengan switching intention maka ternyata kondisi tersebut hanya sedikit menyebabkan mereka ingin berpindah dari kampus tersebut.

Inti dari penelitian ini meliputi; Kondisi service encounter pada pelayanan administratif secara langsung berpengaruh terhadap service quality yang dirasakan mahasiswa pada Perguruan Tinggi di Jawa Barat. Kondisi service encounter pada pelayanan administrative secara langsung berpengaruh terhadap service recovery effort yang dirasakan mahasiswa pada Perguruan Tinggi di Jawa Barat. Kondisi service quality berpengaruh terhadap service recovery effort yang dirasakan mahasiswa pada perguruan tinggi di Jawa Barat. Kondisi recovery effort secara langsung berpengaruh terhadap switching intention mahasiswa pada perguruan tinggi di Jawa Barat. Kondisi service encounter secara langsung berpengaruh terhadap switching intention mahasiswa pada perguruan tinggi di Jawa Barat. Kondisi service quality secara langsung terhadap switching intention mahasiswa pada Perguruan tinggi di Jawa Barat. Kondisi service encounter secara tidak langsung mempengaruhi switching intention mahasiswa yaitu service recovery effort yang dilakukan oleh Perguruan Tinggi di Jawa Barat. Kondisi 
service quality secara tidak langsung dilakukan oleh Perguruan Tinggi di Jawa berpengaruh terhadap switching intention Barat.

yaitu melalui service recovery effort yang

\section{REKOMENDASI}

Dalam konteks untuk meningkatkan pelayanan administrasi kepada mahasiswa, teknologi yang diterapkan perlu diimbangi dengan peningkatan sikap karyawan kontak. Dalam kaitan ini karyawan kontak atau petugas administrasi perlu senantiasa menunjukkan sikap positif ketika melakukan kontak dengan mahasiswa. Hal ini penting untuk meningkatkan citra perguruan tinggi. Perlu dilakukan upaya yang sungguh-sungguh untuk memberikan perbaikan pelayanan apabila terjadi kegagalan. Hal ini penting untuk meningkatkan kenyamanan mahasiswa selama menempuh pendidikan. Perbaikan pelayanan dapat diberikan dengan memberikan penjelasan yang memadai ataupun memberikan kompensasi atas kegagalan yang terjadi. Penelitian ditunjukkan bahwa service recovery effort berpengaruh terhadap switching intention walaupun tingkat pengaruhnya rendah. Akan tetapi kondisi tersebut menunjukkan bahwa di masa datang terdapat potensi bahwa ketidaknyamanan yang dirasakan mahasiswa sebagai akibat lemahnya upaya service recovery effort dapat menyebabkan keinginan berpindah mahasiswa. Untuk itu perlu dilakukan upaya agar kondisi ketidaknyamanan tersebut tidak terjadi. Kondisi ini juga harus dapat menjadi awal penting untuk meningkatkan kualitas hubungan perguruan tinggi dengan mahasiswa.

\section{DAFTAR PUSTAKA}

Azra, Republika Online 7 September 2006.

Analoui F., 1995. Workplace Sabotage: Its Style, Motives and Management, Journal of Management Development. Vol 14 No. 7

Bamford, David and Tatiana Xystouri. 2005. A Case Study of Service Failure and Recovery within International Airline. Managing Service Quality. Vol. 15 No. 3

Berry, Leonard L. 1995. Relationship Marketing of Srvices - Growing Interest, Emerging Perspectives. Journal of Marketing Science. Volume 23. No. 4

Bitner, Mary Jo., Bernad H. Booms and Lois A. Mohr. 1994 Critical Service
Encounters: The Employee View Point. Journal of Marketing. Vol 58 No. 4

Bitner, Mary Jo. Stephen W. Brown and Matthew L. Meuter. 2000. Technology Infusion in Service Encounter; Journal Academy of Marketing Science Vo. 28 No. 1

Berry, Leonard, Kathleen Seiders dan Dhruv Grewal. 2002. Understanding Service Convenience. Journal of Marketing, July.

Christoper, Martin and Andrian Payne. 2001. Relationship Marketing: Bringing Quality, Customer Service, Marketing Together. Butter Worh Heinemann Ltd. Jordan Hill. Oxford. 
Christopher Martin, Adrian Payne and David Ballantyne. 2002. Relationship Marketing: Creating Stakeholder Value, Butterworth Heinemann, MA.

Davis, Mark M dan Janelle Heineke. 2003. Managing Services; Using Technology to Create Value. Mc Graw Hill.

Donaldson, Bill, Tom O' Toole. 2002. Strategic Marketing Relationship. England: John Willey and Sons, Ltd.

Giacalone, Robert A., 1990. Employee Sabotage: The Enemy Within. Supervisory Management, Vol 35 N. 7

Gwinner, Kevin P., Dwayne D. Gremler and Marry Jo Bitner. 1998. Relational Benefts in Service Industries: The Customer's Perspective, Journal of The Academy of Marketing Science. Vo. 26 No. 2

Harris, Llyod $\mathrm{C}$ and Emmanuel Ogbonna. 2006. Service Sabotage; A Study of Antecedents and Consequences, Journal of The Academy of Marketing Science, Vo. 34 No. 4

Harris, Llyod $\mathrm{C}$ and Emmanuel Ogbonna, 2002. Exploring Service Sabotage: The Antecedent, Types and Consequences of Frontline, Deviant, Antiservice Behavior, Journal of Service Research, Vo. 4 No, 3.
Hoffman, Douglas K. Scott w. Kelley and Holly M. Rotalsky. 1995. Tracking Service Failures and Employee Recovery Effort. Journal of Services Marketing Vo. 9 No. 2.

Jones, Michael A., David L. Mothersbaugh dan Sharon E. Beatty. 2000. Switchin Barriers and Repurchase Intention in Service. Journal of Retailing Volume 76 (2).

Lovelock, Christopher and John Wirtz. 2004. Service Marketing: People, Technology and Strategy. Pearson. Prentice Hall.

Mattila, Anna S. 2006. The Power of Explanation in Mitigating the IllEffects of Service Failure. Journal of Service Marketing. 20/7.

Price. Linda L., Eric J. Arnould and Patrick Tierney. 1995. Going Exteremes: Managing Service Encounters and Assesing Provider Performance. Journal of Marketing Vol. 59.Warta Ekonomi, 7 Februari 2006

Zeithaml, Valerie A. dan Mary Jo Bitner. 2000. Services Marketing; Integrating Customer Focus Accros the Firm. 